QIJIS: Qudus International Journal of Islamic Studies

Volume 4, Issue 2, August 2016

\title{
MEDIA: CAUSES AND STRATEGIES TO OVERCOME ISLAMOPHOBIA \\ (PSYCHOLOGICAL AND SOCIOLOGICAL STUDY)
}

\author{
Ratna Istriyani and Yuliatun \\ STAIN Kudus, Central Java, Indonesia \\ ratna.istri@gmail.com
}

\begin{abstract}
A stereotype appears and describes that Islam is the cause of a series of terror. Therefore, some states are worried and suspicious toward Muslims (Islamophobia) up to the present. Islamophobia associated with negative prejudices against Muslims and Islam, and lead to construction of anti-Islam. Prejudice is based on a claim that Islam is an inferior religion and can threat the dominant values in society. The phenomenon of Islamophobia can be assessed by two perspectives: sociological and psychological. In the case of Islamophobia, media became the object of analysis because it has the dichotomy function. They become the cause for the outbreak of Islamophobia symptoms (latent functions). On the other hand, the media is an information agent which has role to provide education and social change effects (manifest functions). Thus, the media can be an instrument or strategy to overcome the turmoil of Islamophobia by involving a synergy of government, Islamic organizations, and institutions of higher education.
\end{abstract}


Keywords: Media, Causes, Strategy, Islamophobia.

\section{A. Introduction}

The development of mass media today are quite encouraging (both print and electronic), and supporting activities of society in different social strata. Therefore, the mass media is often used as a tool to transform the information from two directions, namely from the media towards society, or transform information between itself (Bungin, 2001: 1)

Recently, the influence of the mass media is very extensive, because it can bring everything that happens in the world every day. News about various lives is published widely to the public. As far as possible, the news that is published by mass media does not harm one party, the company's own mass media sources or subjects even reported. One of human needs, both as individuals and as members of society, is information.

Through information, people can update various events that occurred nearby area or around the world. So, information from media gives knowledge to society. With the speed and precision of the mass media in presenting information, the public should not worry to miss the news because with today's sophisticated technology, the mass media have capability to penetrate time and space. Information about collapse of the World Trade Centre and the Pentagon in the United States and the first Bali bombing in Indonesia, are the example of the speed of mass media reported the tragedy.

After a WTC tragedy in New York, on 2001, which was highlighted by media, the Islamic community became a central issue. The Islamic community was assumed as the cause of the problems of the world (particularly terrorism) and became the target of its accusations (stereotype). Therefore, starting on October 1, 2002, American government published a list of suspected terrorists. The Australian Government also did a similar action by setting a series of anti-terrorism rules and raiding several houses of Muslims after the first Bali bombing. 
Indonesia anxiety and accusations against Muslims emerged following the first Bali bombings on 12 October 2002. Anxiety and charges spread along with a series of arrests of suspects and perpetrators of terror such as Amrozi, Ali Imron, Imam Samudra, and Abu Bakar Baasyir. The worst, their attributes and appearance becomes a symbol or representation of terrorism. In other words, emerged a pragmatic construction of society that terrorists synonymous with thick bearded face, koko clothes, cap, and always say the slogan "Allahu Akbar" (Bazian, 2015: 161). Its construction is then led to excessive anticipation attitude towards Islam, especially those who wore such attributes. Even its construction is also trusted by the government and security apparatus.

In this case, media act on emerging and the spread of Islamophobia.It can't be denied that religion is a sensitive issue. None of religious believer who is willing to their religion is used as a scapegoat for an event. No wonder if recently appearing persons who declared as defenders of God. As stated in the study of psychoanalysis that human have instinct of die (tanatos) which appears in the form of aggression, so causes the terrorists didn't fear in order to defend their religion. Relate to the media, such phenomena as if a commodity of information to meet the needs and curiosity of the audience, as well as to capture revenue from advertising. While the capitalist perspective, entertainment and culture has been transformed into the industry. The mass media as a business has goal to obtain maximum profit. Capitalist prefer take into account economic terms rather than paying attention to the socio-cultural aspect (the public). In this aspect, Thedore Adorno and Mark Horkheimer (Durham and Kellner, 2006: 52) state that the media are accomplices of Capitalist that spread a deception. In this context, they saw that the media is a new instrument of domination through modification of various aspects of life, which in this case according to the views of the authors, not only in the entertainment aspect but also the news or broadcasting.

Based on these matters, need to be seen that the media 
has two aspects. On the one hand, the information reinforces the existing social values; but on the other hand media can shapes new social values or new construction. Thus, the media have the ambivalent effect. The positive effect is if the media focuses on the function of informing and educating. If media focus on accentuating the entertainment (to entertain) and coaxing (to persuade), it can cause a number of negative effects to the society. Therefore, the media have multiple effects in relation to the phenomenon of Islamophobia. On one side, media can be a cause of rise of Islamophobia; on other side can also be a strategy in to overcome Islamophobia. Based on the above, this paper examines two points. First, the media is as the cause of Islamophobia. Second, media is as a strategy to overcome Islamophobia with the psychological and sociological perspective.

\section{B. Symptoms of Islamophobia}

Islamophia is a combination of two words, Islam and Phobia. Islam refers to monotheistic religion or belief which states that Mohammed is the prophet of Allah (Rasulullah). Phobia is an extreme and irrational fear of a thing (in Alshammari, 2013: 178). Thus Islamophobia synonymous with fear, anxiety and phobia against Muslims, could even include a set of processes that have an impact on the law, economic, and society (Bazian, 2015: 162). Excessive anxiety and fear often lead to acts of discrimination against Muslims.

One example of excessive anxiety are cases of wrongful arrests of suspected terrorists by the Densus 88 in Solo in late 2015, and death of Siyono at the time of arrest which culminate in the problem of human rights violations on February 2016. It incident illustrates that anxiety and excessive vigilance of the security apparatus became source that has led to pragmatic action without looking at the root of the problem. Such actions indicate that Islamophobia can destroy a person's rationality.

It thus also overrides Tahera Ahmad Muslim, community members at Northwestern University of Chicago who received 
discriminatory treatment from flight attendant in the United Airlines. A flight attendant gives beverage cans that have been opened earlier, the reason is not to be used as a weapon by Tahera. Even other passengers actually support flight attendant action with a reason that Tahera is a Moslem. The incident shows that the discriminatory measures because of extreme fear against Islam occurred in various lines of society, and not look at men and women.

The study of Islamophobia began in 1995 in England. Some studies show that Islam is perceived as a threat. Islam is considered to have similarities with the Nazi and communist that contain of an overview of the invasion and infiltration. Fear and hatred of Islam then continued on fear and distaste to the majority of the Moslems. Hatred is underway in several Western countries. The last twenty years, hatred towards Muslims increasingly revealed with more extreme and more dangerous (Truts in Moordiningsih, 2004: 74). In America, extreme suspicion and negative perceptions toward Islam is widespread after September 11, 2001. Various skewed perceptions are as follows:

1. The Islam Religion portrays a monolithic culture and it is Relentless to accept the emerging realities in the society.

2. Islamic religion has completely different values in comparison with other Faiths and cultures.

3. Islam is inferior Considered as perceived by the west. It is deemed to have barbarism traits, archaic, and relatively irrational.

4. Islam religion supports various acts of terrorism and general violence in the society.

5. Islamic religion is a violent ideology in the political arena (Alshammari, 2013: 177).

Perceptions above do not doubt constructing that Islam is rigid, barbaric, irrational, and thick with violence. Therefore, it later emerged the assumption that a series of terrorist acts identified with Islam.

In Indonesia, symptoms Islamophobia appear after the 
first Bali bomb on October 12, 2002, which killed 202 consisting of foreigners and citizen. Starting from such events, terrorism issue began to boom. Until the arrest of the suspects, they are Amrozi and his friends who use Islam attributes. Finally, fear and vigilance against Islam (especially Radical Islam) were arisen. Furthermore, a series of bombs, both large and small such as bombing of JW Marriot Hotel in 2003, bombing of the Australian Embassy (2004), Bombing of Jimbaran/Bali II (2005), bombing JW Marriot II and Ritz Carlton (2009), bombing Sarinah (2016), and a series of terror events in some areas.

Islamophobia has several characteristics, and there are some keys to understanding these differences (Runnymede in Moordiningsih, 2004: 75), which is open and closed views of Islam. Phobia and fear of Islam is a characteristic of the closed viewa on Islam; while logic disapproval and constructive criticism and appreciation are an open view of Islam.

\section{Media as Cause of Islamophobia (Sociological and Psychological Perspective)}

This sub discussion discusses how the media influence the emergence and spread of Islamophibia in two perspectives, that are Sociological and Psychological perspective. Sociological perspective emphasizes the power relations of media in the information/news constructing or presenting and analyzed with the theory of media representation. While psychological perspective uses a cognitive approach that emphasizes how the people watching and understanding the information that direct to a stereotypical action, which then leads to Islamophobia.

\section{Media Representation}

It cannot be denied that today we live in the information age, along with the cutting-edge technology. Technology support the deployment of information more massive and faster, for the example is the mass media such as television and the Internet that can be accessed easily and cheaply by anyone. The flow of information or news 
could spin so fast and can penetrate through the boundaries of space and time.

Unfortunately, the mass media, especially electronic media, became an instrument and a cause of Islamophobia widespread around the globe, mainly through the canals of news about violence, radicalism, and terrorism which are often associated or identified with Islam. Therefore, it can be described that the media is loaded with political representation. That's why Stuart Hall revealed that the media does not merely reproduce reality or covering the event as it is. Reality was actually established and perpetuated by their language practices. In other words, the media not only transmit the meaning but establish or construct the meaning of reality.

“... The media defined, not Merely Reproduced, 'reality'. Definitions of reality were sustained and produced through all Reviews those linguistic practices (in the broad sense) by means of which selective definitions of 'the real' were represented. But representation is a very different notion from that of reflection. It implies the active work of selecting and presenting, of structuring and shaping: Merely not the transmitting of an alreadyexisting meaning, but the more active labor of making things mean. It was a practice, a production, of meaning: what subsequently came to be defined as a 'signifying practice'. The media were signifying agents ... "(Stuart Hall in Michael Gurevitch, Tony Bennett, James Curran, and Janet Wallacott, 1982: 60).

Thus, a lot of the audience who agrees reality or news conveyed by the media, especially television and internet (letter news/ daily online). In fact, media often exaggerate the reality (hyperreality) so that their reality becomes vague. Especially news about radicalism and terrorism including bombings and shootings are then 
often associated with radical Islamic groups so as to form an opinion on Islam globally. News about the spread of radicalism and terrorism, especially after the WTC bombing on September'11 2001 and the first Bali bombing in 2002, and the media has a major role and cause complex effects on the global world. It's up to the media in Indonesia that informed about bombings; particularly the most recent is bombing in Sarinah Jakarta, in early 2016.

"NIIS bertanggung jawab dalam serangan bersenjata pagi ini dengan target warga negara asing dan petugas keamanan yang mengamankan mereka di Ibukota Indonesia," kata sumber Aamaaq. Indonesia belum memastikan kebenaran dari klaim yang dilansir Kantor Berita Aamaaq tersebut...

Kepala Divisi Humas Polri Irjen Anton Charliyan mencurigai peristiwa tersebut terkait dengan peringatan yang pernah diberikan oleh Negara Islam di Irak dan Suriah (NIIS). Pihaknya mengakui, peringatan itu pernah diterima dari kelompok NIIS pada Desember 2015 lalu.

Namun, peringatan itu benar-benar terjadi. Padahal, pihaknya sudah berusaha menyikapinya dengan melakukan berbagai penangkapan kelompok teroris.

(Reported by news article Kompas Online, posted in January 14, 2016. The title is "Bom dan Ledakan di Sarinah Jakarta, Polisi Sudah Mendapat Peringatan Sebelumnya dari NIIS")

That news was published in a few hours after the bombing incident at Sarinah Jakarta on January 14, 2016. The news using the controversial title: Bom dan Ledakan di Sarinah Jakarta, Polisi Sudah Mendapat Peringatan Sebelumnya dari NIIS (Bomb blast in Sarinah, Jakarta, police had received warnings previously from NIIS). Language and words in a news article is the practice of using language that represents that the bomb blast was an extraordinary event 
because it is fronted by world terrorist and militants. Then, any bombings or radicalism will always be associated with terrorism and NIIS (ISIS), which is then Islam in general associated with such sadistic acts.

The other example is the news on television. Television is a special study for Hall because it has a series of sign that more complex. Not only has the language, the television had a visual and aural aspect. Visual related to focus on the image display that often leads to the bomb victims and perpetrators. While aural associated with audio or exposure broadcasters (including rhythm and emphasis), and is usually done in a tone loud, tense and serious.

In the process of reporting or broadcasting, at least there are two processes, which in terms Hall called the encoding and decoding (cryptanalysis). Domination of encryption/coding into the power of the media is as an agent. The form of encryption is the keyword "bomb" and "suspicion about the bomb incident and NIIS warning". Addition, on television, focuses on the image of terrorists who wear the attributes which symbolizes Islam (cap, koko, etc) or image of injuries or died victims shortly after the incident.

The process encoding which involves a process of decoding or code reading (meaning) -according to Hall- can give effects, influence, entertainment, persuasion with the many consequences.

"... It is this set of decoded meanings " have an effect ; influence, entertain, instruct or persuade, with very complex perceptual, cognitive, emotional, ideological or behavioral consequences ... "(in Durham and Kellner (ed), 2006: 165)

Thus, news about the series of bomb or terrorist acts such previous footage can makes an impact and consequences 
of perception and cognition of Islam were represented cruel and harsh. The consequence that is more damaging was directed to the emotions and discriminatory habits (behavioral) against Islam and its adherents. Then the most feared is the ideological consequences associated with the ideas and viewpoints of Islam. In other words, indirectly media have legitimized or confirmed views of the people in the outside world about Islam. As described by Alshammari (2013: 177):

"... Islam is inferior Considered as perceived by the west. It is deemed to have barbarism traits, archaic, and relatively irrational, Islam religion supports various acts of terrorism and general violence in the society, the Islamic religion is a violent ideology in the political arena."

Islam is seen as a religion of violence and embraces the ideology of violence, so it is considered cruel, archaic and irrational. Thus, Islam has always connected with the bombings, mass murder or terrorism. Though, the terminology Islam is refers to salvation or peace. Violence, radicalism, and terrorism are only done by handful people who bring Islam attributes. For that reason, the implications against the Muslims.

No wonder if then appear excessive anticipatory actions against the Muslims. So that cases of fault arrest suspected terrorists and perpetrators and discrimination against Tahera in public space could occur. Thus, we can see media to be one trigger rising of Islamophobia or excessive fear of Islam was later implicated in a series of acts of discrimination against Muslims in various aspects of life, both in the macro and micro context.

\section{Media, Islamophobia, and Cognitive Approaches}

The spread of Islamophobia by media also can be studied with cognitive approach that refers to the ability 
of people or individuals to view or read and understand the information from the media and the environment. In the psychological context, Ashmore and Delbolca (in Moordinigsih, 2004: 76) explain that the cognitive approach emphasizes on how social information is received, processed, and recognized in the memory.

In the case of virus or plague of Islamophobia, not only stop on the process of receiving information related to Islam through the media, but also the appearance of stereotypes act or negative view of Islam which not only done by non-Muslims and even fellow Muslims. Thus, the cognitive approach by Lipman becomes relevant in the case of Islamophobia. According to Lipman (in Moordinigsih, 2004: 76) emphasizes a cognitive approach to the discussion of stereotypes. Human categorizing and stereotyping to reduce the amount of information must be understood. The term stereotype appeared first to describe the beliefs that are transmitted on the characteristics such as personality, expected behavior, as well as the values of the individual. Prejudice often occurs because error or closure in the processing of any information that stems from stereotypes.

Based on cognitive approach by Lippman, a person's knowledge or stereotypes against Islam and terrorism relies on information provided by the media. As described in the previous exposure that the news has been emerged the extreme and irrational prejudice against Islam. Linking of bombings with the militant is such as ISIS. But actually the information is unconfirmed accurately. Therefore, the news would cause excessive fear and prejudice that are less grounded and less analysis. In other words, the public has tended to categorize and stigma. Moreover, according to Lippman, stereotypes are usually done to minimize information that overload. Meanwhile, television channels and news or articles online are too much. They give the same news review. Therefore, a lot of information that is 
scattered in the community emerged stereotypes.

The worst is what is happened in the internet media where information can spread very quickly. We often read and find excessive news or information (hyperbola) and fault that often called $a$ hoax or fake news. The fake news often causes panic. Yet the reality or information needs to be confirmed and it is not as bad as reported. Therefore, Islamophobia spread so quickly because the community itself is easy to get caught up in hyper reality or fault reality. Actually, television and the Internet could be a tool of political economy, or to obtain the profit. The reality that we see today, media vying to present the update news show the content consisting hyperbole can attract the attention of the audience.

The two approaches above shows that Islamophobia is influenced by the information, whether the information of the individual or which are available (especially from media). Then its information can't be separated from the views that exist within the community about Islam and the Islamic community. Regard to information, the media have a central role in providing information to the public and be able to cause anxiety to Islam (Islamophobia).

\section{Media as Strategy to Overcome Islamophobia}

Majority Indonesia's population is Muslim, so Islam has become a central issue in the context of religious life. The reality cases of radicalism, violence, religious conflict, and a series of bomb tragedy in some public places be one cause of the fear or the seeds of Islamophobia. The most worrying is the fear that emerged among Muslims themselves. The implication could lead to the fragmentation of Muslims.

Islam came to bring a peace, justice and the rule is expected to be brought into a better social order. Islam teaches peace to all classes, except the parties who interfere with and hinder Muslims to carry out the rules of Islam. 
Open view of Islam need to be built and closed views need to be minimized, of course it is not as easy when it has been internalized by some members of the community.

A strategy is needed to counter the spread of Islamophobia. When Moslems have the self-esteem, they don't worry about the fear of other parties against Islam. However, the Muslims will be more dignified if it arises a respect because Islam is perceived bring benefits in the lives of human beings.

As described in the presentation earlier that the media is considered to be one of the causes of outbreaks of Islamophobia since the preaching inaccurate and exaggerated the events terror that occurred in Indonesia and in the global world. Even, pragmatically media take economic advantage of the attention and anxiety arising from the audience or the communicant. Nevertheless, it is necessary to build an optimistic thinking to the media, especially in the Indonesian context. Moreover, the majority of Indonesia's population is Muslim, and there are scholars who have power or strategic position to cooperate with the media and confirm the issues that led to issue of Islam. Thus, the media really becomes a window to expand the view and allows us to understand what is happening around without a tendency. Media is an agency that uses language practices that can explain and give meaning (Stuart Hall, 1982). In this case, the media can give constructive meaning to events or things that are separate and unclear about Islam and a series of terror.

Before linking with the media, need to look at the study or analysis of the Strengths-Weaknesses-OpportunitiesThreats (SWOT) matrix. SWOT matrix is on of a tool to help build four types of strategies. Moordingsih (2004) uses the concept from F.R David to organize a SWOT analysis in Indonesia as a base to organize the strategy. SWOT Analysis, among others, as follows: 


\begin{tabular}{|l|l|}
\hline Strengths & $\begin{array}{l}\text { The majority of the population is Muslim, the people } \\
\text { of Indonesia have motivation TO CE ONCERN in } \\
\text { Islam, there is the rise of the youth of Islam }\end{array}$ \\
\hline Weaknesses & $\begin{array}{l}\text { negative perceptions of Islam, negative and closed } \\
\text { information about Islam, attributes Islam makes } \\
\text { the Islamists be exclusive or closed, different } \\
\text { perception of jihad and da'wa, the absence of the } \\
\text { figure who guide to the people to face the reality, } \\
\text { the implementation of Islamic rules still minimal, } \\
\text { the public's understanding of Islam is still limited }\end{array}$ \\
\hline Opportunities & $\begin{array}{l}\text { Government fairly accommodating, institutions } \\
\text { research is neutral, there are organizations and } \\
\text { Islamic parties, there is a group of Islamic studies }\end{array}$ \\
\hline Threats & $\begin{array}{l}\text { There is a claim that Islam is inferior and Islam is } \\
\text { barbaric. }\end{array}$ \\
\hline
\end{tabular}

Based on the SWOT analysis, it builds four strategies to overcome Islamophobia cases. They are as follows:

\begin{tabular}{|c|c|}
\hline $\begin{array}{l}S t r e n g t h \\
\text { Opportunity } \\
\text { Strategy }\end{array}$ & $\begin{array}{l}\text { Islamic organizations and government cooperate } \\
\text { as partners, research that accommodate the } \\
\text { development of Islam in a social group }\end{array}$ \\
\hline $\begin{array}{l}\text { We a } k \text { nes } s \\
\text { Opportunity } \\
\text { Strategy }\end{array}$ & $\begin{array}{l}\text { clear information about Islam by Islamic } \\
\text { organizations, clear information about the } \\
\text { relationship of Islam with other groups, research } \\
\text { by Muslim scientists who can provide information } \\
\text { management, research on unity, the perception of } \\
\text { Jihad in the present }\end{array}$ \\
\hline $\begin{array}{l}S t r e n g t h \\
T h r e a t\end{array}$ & $\begin{array}{l}\text { Build the self-image of Islam, especially at the } \\
\text { level of the younger generation, solve the social } \\
\text { problems }\end{array}$ \\
\hline
\end{tabular}




\begin{tabular}{|l|l|}
\hline \multirow{W}{*}{ e a k n e s s } & $\begin{array}{l}\text { Improving the public's understanding of Islam with } \\
\text { various media, facilitating access to study Islam, } \\
\text { transmitting "fun" experience and understanding } \\
\text { about Islam, Islam attributes are not be an reason } \\
\text { Strategy } \\
\text { to make justification that a group is an exclusive } \\
\text { group and barbar, formulating the concept of } \\
\text { jihad through information technology, politics, } \\
\text { economics, education and social culture. }\end{array}$ \\
\hline
\end{tabular}

The strategy focuses on key factors both internally and externally. SO strategy is a strategy that uses the internal strength to take the external opportunities; WO strategy is a strategy to help overcome internal weaknesses by taking advantage of external forces; ST strategy is a strategy of using force to reduce the threat of internal/external power; and WT strategy is a strategy with defensive tactics to reduce internal weaknesses and avoid external threats (David in Moordingsih, 2004).

From the exposure of the above are important points related to overcome Islamophobia, especially in Indonesia. The media became an instrument or agent which gives information that can rehabilitate pastures or the negative stereotypes of Islam over the years. In other words, the media play a role in constructing Islam through a series of existing information. Of course, information and analysis should be balanced. At this level the research of educational institutions (Universities or Research Institutions Independent) become a scientific and valid source in order to provide insight into a series of news related to terrorism and radicalism. The government in cooperation with Islamic organizations in charge controls the work of the mass media and electronic. Synergy of these actors (government, Islamic organizations, Institutions Education/Research, and media) was able to minimize the macro effects of Islamophobia as conflict and violence. 


\section{Conclusion}

Phenomenon of Islamophobia began to plague globally, including Indonesia. The phenomenon is increasingly booming especially after a series of terrorist acts in the United States in 2001 and in Indonesia after the first Bali bomb in 2002. Accelerating the spread of Islamophobia is affected by the news or representations of bombings that has always been associated with forms of terrorism and involves Islam. Information or news on terrorism repeatedly raises precisely cognition or understanding that terrorism is always synonymous with Islam. Thus, Islam is seen as a religion of terror, sadistic and violent. Knowledge is a form of cognitive stereotypes that often leads to discrimination and prejudice against Islam pragmatic

Although the media is one of the triggers outbreaks of Islamophobia, actually media can also be an instrument or strategy to overcome Islamophobia. The media can be an instrument construct and rehabilitate stereotypes about Islam during this time. The construct of resources must involve scientific or educational or research institutions research institutions such as universities or LIPI. Then the government in cooperation with Islamic organizations has a role to control the work of media in presenting the news related to terrorism and radicalism. 


\section{REFERENCES}

Alshammari, Dalal. 2013."Islamophobia". International Journal of Humanities and Sosial Science Vol. 3 No.15.

Anonim. 2009. "Daftar Serangan Bom di Indonesia”, (Online), (m.dw. com/id/daftar-serangan-bom-di-indonesia/a-4495798, diakses tanggal 14 Juli 2016 Pukul 09.16 WIB). . 2016. "Bom dan Ledakan di Sarinah Jakarta, Polisi Sudah Mendapat Peringatan Sebelumnya dari NIIS", Kompas (Online), (http://print.kompas.com/baca/2016/01/14/ Bom-dan-Ledakan-di-Sarinah-Jakarta\%2c-Polisi-Sudah-M , diakses tanggal 13 Juli 2016 pada pukul 8.44 WIB).

Bazian, Hatem. 2015. "Islamophobia and The Three Evils of Society." Islamophobia Studies Journal. Vol. 3 No.1.

Burhan Bungin. 2001. Imaji Media Massa. Yogyakarta: Jendela.

Durham, Meenakshi Gigi dan Douglas M. 2006. Kellner. Media and Cultural Studies. USA: Blackwell Publishing.

Michael Gurevitch, et al (ed). 2005. Culture, Society and the Media. London and New York: Routledge.

Moordiningsih. 2004. "Islamophobia dan Strategi Mengatasinya". Buletin Psikologi, 21st Year, No 2. 